\title{
Psychiatry in Turkey
}

\author{
Bulent Coskun
}

Professor of Psychiatry, Kocaeli University Medical School; Director of Community Mental Health, Research and Training Centre, Kocaeli University, email bcoskun@isbank.net.tr

he Republic of Turkey has a population of 67.4 million (year 2000) and covers $783563 \mathrm{~km}^{2}$; administratively it is divided into 81 provinces. A few national statistics from 2000 are: infant death rate 41.9/1000; life expectancy at birth 68 years; unemployment rate $6.6 \%$; gross national product (GN P) per capita U S\$2965; and adult literacy rate

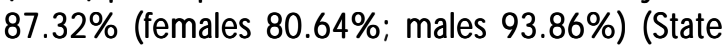
Statistics Institute, 2003).

Turkey is going through a period of continuous transition. Geographically, the country is a bridge between Asia and Europe (for this reason it has historically been a path for invasions and cultural exchanges) and therefore between the Western world and the Middle East. It is a secular republic but a large majority of the population is Islamic, and it is the only country with these features in N ATO and Europe.

Even physically the land is in continuous transition - it is not stable and suffers great damage from earthquakes almost every four or five years, the largest in recent times being on 17 August 1999 in the Marmara region. The state of change is reflected in daily life as well. For example, the traditional, extended family structure is transforming into the more nuclear type. Some traditional national characteristics are being challenged. 'Turning the corner' has been the motto of many people, as the values and preferences of individuals, families and even institutions keep changing. The effects of the long-term high inflation rate, serious financial limitations and separatist activities (with armed conflict in the eastern part of the country) have all played a crucial role. Many people living in the villages have migrated to the peripheries of some of the larger cities or have left the country to work abroad, typically in Germany, France, The $N$ etherlands or Belgium. The specific mental health problems of these migrants have been the subject of comparative studies (Gilleard, 1983; Van der Stuyft et al, 1993; D iefenbacher \& H eim, 1994; Yazar \& Littlew ood, 2001).

Another characteristic feature of Turkey is the series of contrasts seen in almost all aspects of life, which inevitably is reflected in mental health issues, in terms of both psychosocial structure and psychiatric treatment.

$\mathrm{N}$ one the less, there is stability in many respects, and this has an impact on psychosocial well-being. Solidarity often extends beyond family bonds, to members of the same village or even region. In almost every city there are areas where people from the same region of the country live together and offer each other social support.

Another important factor to be considered is the strong interpersonal links among the people. Traditionally people tend to talk about their difficulties and to share their feelings. Although sometimes such social support may be undermined by intrusive and prescriptive attitudes, it is still possible to say that solidarity among people in general helps them to adapt to and overcome difficulties. This was observed after the devastating earthquake in August 1999 in Marmara. While therapeutic help was made available, most of the inhabitants of the tent cities served as 'patient listeners' to each other all through the long, empty days after the earthquake (Aydin, 2001).

\section{Forty years of mental health policy development}

The psychiatry practised in ancient Anatolia and even the relatively well develo ped psychiatric services during the period of the 0 ttoman empire are beyond the scope of this paper, which focuses on current psychiatry in Turkey. But to understand today and the vision for tomorrow, a brief overview of the recent development of mental health policy is necessary.

In the 1960s, improvements to the curative and rehabilitative services through their vertical organisation was the goal. Mental health dispensaries in Istanbul and Ankara served as extensions of the mental hospitals and so had only a limited remit regarding prevention and mental health promotion. At that time, a stand was taken against use of the Turkish equivalent of 'lunatic' and for its replacement by a term equivalent to 'mentally ill patient'. Efforts were made by the Ministry of $\mathrm{H}$ ealth to prepare a mental health policy, although only a few meeting notes remained when the next attempt at the same Ministry was made in the 1980s (Bayülkem, 1998).

At the time of the second attempt to draw up a policy on mental health, in the 1980s, I was in charge of the mental health department at the Ministry of $\mathrm{H}$ ealth. The goal then was the integration of mental health into primary health care (i.e. a horizontal approach) with promotion and prevention activities in addition to the improvement of curative services. For inter-sectoral and inter-disciplinary coordination there were efforts to get the involvement of different ministries, universities and non-governmental organisations, with the support of the World Health O rganization (W HO ). Five regions were established, each with one of the country's five mental hospitals at the centre. Regulations were put in place regarding referral to those centres and the follow-up of patients after discharge. The role of provincial mental health divisions was detailed, with emphasis on local mental health coordination councils (Coskun, 1987, 1988). Although most of the plans were prepared in close collaboration with regional and local staff, their implementation was limited and not much could be achieved in terms of a permanent outcome.
At the time of the second attempt to draw up a policy on mental health, in the 1980s, I was in charge of the mental health department at the Ministry of Health. The goal then was the integration of mental health into primary health care (i.e. a horizontal approach) with promotion and prevention activities in addition to the improvement of curative services. 
Through the early 1990s, there were health reform studies at the Ministry, where mental health issues were discussed once more. Most important in that decade was the epidemiological study of mental health (Erol et al, 1998). After the Marmara earthquake in 1999, the need for an overall policy with local action plans was once more realised at ministry level. A more organised process has been planned, with the financial support of the World Bank; a permanent but flexible structure is now being worked on, with contributions from different sectors and disciplines (Ulug, 2003).

\section{Provision of psychiatric services}

Most psychiatric services are provided by hospitals attached to the Ministry of $\mathrm{H}$ ealth. The private sector accounts for only 150 of the total of 6146 beds. At the five mental hospitals run by the Ministry of $\mathrm{H}$ ealth there are 5570 beds in total, while the two hospitals attached to the M inistry of Social Security have 426 beds (M inistry of $\mathrm{H}$ ealth, 2002). A considerable portion of these beds are still occupied by long-stay patients, which limits the number of beds available for other patients, many of whom are therefore repeatedly re-admitted shortly after being discharged too soon. The programme on referral procedure mentioned above, with special guidelines for patient follow-up at a local health centre after discharge, was planned to decrease the number of repeat admissions, but the new procedure has not been universally adopted.

The number of psychiatric beds in general hospitals is not detailed in the current statistics, but the number of psychiatrists working at general hospitals gives an idea of the scale of those institutions' provision of psychiatric services: of the 398 psychiatrists working at hospitals attached to the Ministry of $\mathrm{H}$ ealth, 238 work in general hospitals and 138 at the five specialist psychiatric hospitals. The tendency to set up psychiatry divisions at general hospitals has increased the provision of local help for people with psychiatric problems. Psychiatrists mainly work in large cities and in the western parts of the country. According to the figures of the Psychiatric Association of Turkey, 760 psychiatrists out of 1149 (i.e. around twothirds) are located in Istanbul, Ankara and Izmir.

This uneven distribution also pertains to psychologists. Six psychology departments provide master and doctorate education. Legally (as set out in a statute dating from 1930) clinical psychologists must work under the supervision of psychiatrists. But especially in large cities there are many private clinics run by psychologists, a few of whom are without proper clinical psychology training. $0 \mathrm{n}$ the other hand, most clinical psychologists are well trained, but they need their legal status to be looked at urgently. Similar to psychiatrists, 149 of 266 psychologists w orking within the M inistry of $\mathrm{H}$ ealth are at general hospitals, compared with 34 w orking in specialist psychiatric hospitals.

There are few psychiatric social workers and psychiatric nurses; most of the latter work within higher nurse education. $\mathrm{N}$ one the less, there are many highly experienced nurses working in psychiatric clinics, although they are not entitled to call themselves psychiatric nurses.
An epidemiological study was carried out by the Ministry of $\mathrm{H}$ ealth on the mental health status of the Turkish population (Erol et al, 1998). Among the representative sample of 7479 people the prevalence of psychiatric disorders in the past 12 months according to ICD-10 criteria was $17.2 \%$. The three most common psychiatric illnesses were pain disorder $(8.4 \%)$, major depression $(4 \%)$ and a specific phobia $(2.7 \%)$. The professional first contacted for psychological problems was: a psychiatrist (39\%), another specialist (e.g. an internist or neurologist) (33\%), a general practitioner $(21 \%)$ or a religious healer $(3.6 \%)$. The three disorders with the highest rates for any contact were: panic disorder, obsessive-compulsive disorder and somatisation disorder.

The same report revealed that antidepressants were the most commonly used psychotropic medication. Five per cent of the general population interviewed were using psychotropic agents (antidepressants were used by $66 \%$ of these, sedatives by $23 \%$, antipsychotics by $7 \%$ and antiepileptics by $2 \%$ ). Fifty-one per cent had received medication from 'other' specialists, $22 \%$ from psychiatrists, $18 \%$ from general practitioners and $5 \%$ from pharmacists, while $4 \%$ had taken them without making a professional consultation (Erol et al, 1998).

0 ther than the above-mentioned disorders, conversion disorder and dissociative disorders are commonly observed and draw scientific attention (Tutkun et al, 1998; Sar et al, 2000; Kuloglu et al, 2003).

There are some newly founded associations that focus on the rights and welfare of psychiatric patients and their relatives, most of which are currently led by professionals who wish to promote 'consumer-led' services (Ankara U niversity Psychiatry D epartment, 2000). This support for patients' rights follows on from more general discussions of human and consumer rights in the country.

\section{Education and research}

Mental health education and education in the behavioural sciences are overlapping areas in the formal training of different disciplines. At medical schools, in addition to behavioural sciences in the first year, theoretical and practical psychiatry is provided in later years, and there is a four-week practical course in the final year.

It is often argued that six years of medical training is not sufficient to equip the practitioner with the necessary knowledge and skills to handle psychiatric evaluation and care, so that in-service training is needed to provide better integrated care at primary health care level. Sometimes there are discussions regarding the motivation for those inservice training programmes - there is a view that some programmes are to 0 closely associated with the pharmaceutical industry and attempt to encourage the use of medication by specialists other than psychiatrists and by local primary care practitioners.

Psychiatric training is provided at 36 university psychiatry departments and 12 training hospitals, most of 
which are attached to the Ministry of $\mathrm{H}$ ealth. $\mathrm{C}$ hild and adolescent psychiatry has been a separate specialty since 1995.

An increasing number of multi-centre research projects are being carried out, some with international collaboration (U stun \& Sartorius, 1995). The psychiatry department at H acettepe $U$ niversity is a co llaborating centre of the WHO.

Some other topics for research include: the pathways to psychiatric care, the use and effectiveness of psychotropic drugs, the effects of disasters, consultation- liaison psychiatry, attitudes and behaviour towards people with a mental illness, and the epidemiology of some psychiatric disorders.

\section{Law and ethics}

Ethical rules for psychiatric practice were established in June 2002 by the Psychiatric Association of Turkey; the rights and responsibilities of psychiatrists were underlined with reference to patients' rights, and recommendations were set out on ethical issues regarding research and publication procedures.

So me mental health issues are covered in articles of the Turkish constitution, such as the duty of the state to provide for the physical and mental health of individuals, and the rights to live freely and to develop physical and mental well-being; limitations to these rights can be defined only by law, and there is a prohibition against torture and the undermining of human dignity.

The civil law was renewed in January 2002. It now details the civil rights of citizens and the conditions for the limitations of those rights; it also covers the marriage and divorce of mentally ill people.

The criminal law stipulates special conditions for the treatment of mentally ill offenders.

Lack of an overall mental health law continues to be a concern for the mental health profession. The Psychiatric Association of Turkey has chosen to begin work on a draft law for the protection of the rights of psychiatric patients, rather than a 'mental health law'. In this draft there are items on principles relating to, for example, the rights of patients, including issues on privacy, consent to treatment and involuntary hospitalisation, as well as the roles of psychiatrists and judges. Currently the congruency of this draft and implementations of the new civil law are being studied. The next step will be to send the revised draft to the Ministry of Justice for amendment, before it is submitted to parliament.

\section{Conclusions}

In Turkey at present, the main concerns for psychiatry are:

0 the development of a mental health policy

O improved education and training in psychiatry

O better psychiatric care

0 increasing the amount of collaborative research

o work against stigmatisation

o collaboration with the consumers of mental health services and their relatives
O the integration of a mental health component into primary health care and general health care

o mental health promotion and illness prevention.

The rapid changes in socio-economic conditions, the effects of the media, the unstable socio-political situation, the high percentage of young people in the population, unemployment and people not being able to get higher education are other, more general areas of concern.

The national decision makers do not seem to be aware of the effects of psychosocial realities beyond referring to these issues in their public speeches. Mental health specialists should spare more time and energy to collaborate with decision makers at local and national level, bearing in mind that the improvement of mental health and psychosocial well-being is far beyond the capacity of (mental) health specialists to deal with by themselves.

\section{References}

Ankara U niversity Psychiatry Department (2000) Associations and Foundations Acting on M ental Health Issues in Turkey [in Turkish], pp. 3-48. Ankara: 36th $\mathrm{N}$ ational Psychiatry Congress Press.

Aydin, M. (2001) Relationship Between Perception of Trauma and Attribution of Meaning and the Development of PTSD among Individuals Who Experienced the M armara Earthquake [in Turkish], pp. 81-84. Dissertation thesis, Kocaeli University.

Bayülkem, F. (1998) Historical Development of Neurology, N eurosurgery and Psychiatry in Turkey [in Turkish], pp. 155-165. Istanbul: Arbas.

Coskun, B. (1987) Resources, difficulties and solutions regarding mental health services in Turkey [in Turkish]. Toplum ve Hekim, 44, 11- 15

Coskun, B. (1988) Activities of the Department of Mental Health [in Turkish]. Mental Health Bulletin, $1,7$.

Diefenbacher, A. \& Heim, G. (1994) Somatic symptoms in Turkish and German depressed patients. Psychosomatic Medicine, 56, 551-556.

Erol, N., Kilic, C., Ulusoy, M., et al (1998) Report on the Mental Health Profile of Turkey [in Turkish], pp. 95-100. Ankara: Eksen Tanitim.

Gilleard, E. (1983) A cross-cultural investigation of Foulds' hierarchy model of psychiatric illness. British Journal of Psychiatry, 142, 518-523.

Kuloglu, M., Atmaca, M., Tezcan, E., et al (2003) Sociodemographic and clinical characteristics of patients with conversion disorder in eastern Turkey. Social Psychiatry and Psychiatric Epidemiology, 38, 88-93.

Ministry of $\mathrm{H}$ ealth (2002) Statistics of the General Directorate of Curative Services. Available on CD-ROM. Istanbul: Ministry of Health.

Sar, V., Tutkun, H., Alyanak, B., et al (2000) Frequency of dissociative disorders among psychiatric outpatients in Turkey. Comprehensive Psychiatry, 41, 216-222.

State Statistics Institute (2003) Turkey with Statistics 2002, pp. 14. Ankara: State Statistics Institute Press.

Tutkun, H., Sar, V., Yargic, L. I., et al (1998) Frequency of dissociative disorders among psychiatric inpatients in a Turkish university clinic. American Journal of Psychiatry, 155, 800-805.

Ulug, B. (2003) N ational Mental Health Policy Conference convened in Ankara [in Turkish]. Bulletin of the Psychiatric Association of Turkey, 3, 6.

Ustun, B. \& Sartorius, N. (1995) Background and rationale of the WHO collaborative study on 'Psychological Problems in General Health Care'. In M ental IIIness in General H ealth Care: An International Study (eds T. B. U stun \& N. Sartorius), pp. 118. N ew York: Wiley.

Van der Stuyft, P., Woodward, M., Armstrong, J., et al (1993) Uptake of preventive health care among Mediterranean migrants in Belgium. Journal of Epidemiology and Community Health, 47, 10-13.

Yazar, J. \& Littlew ood, R. (2001) Against over-interpretation: the understanding of pain amongst Turkish and Kurdish speakers in London. International Journal of Social Psychiatry, 47, 20-33.
Some mental

health issues are covered in articles of the Turkish constitution, such as the duty of the state to provide for the physical and mental health of individuals, and

the rights to live freely and to develop physical and mental wellbeing. 